\title{
"Los que comen coca son hicheseros": demonología y la coca en la obra de Guaman Poma de Ayala
}

\author{
"Those who eat coca are sorcerers": Demonology and Coca in the Works \\ of Guaman Poma de Ayala \\ Giovanni Salazar-Calvo \\ Michigan State University, Michigan, Estados Unidos \\ Contacto: salaza63@msu.edu \\ https://orcid.org/0000-0001-6139-1592
}

\begin{abstract}
Resumen
En este ensayo, argumento que Guaman Poma de Ayala utilizó estratégicamente discursos demonológicos para representar de manera peyorativa la utilización de la coca en el mundo andino. No obstante, en algunos pasajes de su obra, el cronista andino arguye que un empleo regulado de este arbusto no impide que el virreinato se desarrolle ordenadamente. Propongo que la estrategia guamanpomiana consiste en afirmar que esta planta no impide que los incas gobiernen el virreinato de Perú mano a mano con los españoles. Al utilizar discursos demonológicos, el cronista atrae hacia sí la simpatía de sus lectores cristianos; sin embargo, simultáneamente pone en marcha procedimientos que retratan positivamente la sociedad inca y su uso regulado de la coca en contextos económicos y civiles. Dicha estrategia le permitió defender la idea de que los incas tenían la capacidad de ejercer el poder político junto con los españoles, sin entrar en conflicto directo con los presupuestos teológicos europeos.
\end{abstract}

Palabras claves: Felipe Guaman Poma de Ayala; Coca; Demonología; Fármaco; Idolatría; Gobierno inca.

\begin{abstract}
In this essay I argue that Guaman Poma de Ayala strategically used demonology-related discourses to negatively represent the consumption of coca in the Andean world. Said this, the native chronicler also claimed that the use of this plant did not hinder the orderly development of the viceroyalty. I propose that Guaman Poma's strategy intends to confirm that coca did not prevent the Incas to govern the viceroyalty of Peru along with the Spaniards. By means of demonology-related discourses, the author most likely gained the sympathy of his Christian readers. At the same time, however, he started a way to look at Inca society and its use and consumption of coca in a positive light when talking about
\end{abstract}


economic and civil matters. This strategy allowed him to defend the idea that the incas were able to use political power along with the Spaniards without any conflict with European theological principles.

Keywords: Felipe Guaman Poma de Ayala; Coca; Demonology; Pharmaco; Idolatry; Inca government

Recibido: 10.10 .19

Aceptado: 20.12 .19

"Todos los que comen coca son hicheseros que hablan con los demonios, estando borracho o no lo estando y se tornan locos lo[s] que comen coca." (Guaman Poma, 2001 [1615], p. 2801)

Alrededor de 1615, Guaman Poma de Ayala le dedicó al rey Felipe III su Nueva corónica y buen gobierno, obra de casi 1200 páginas que versa sobre la historia del imperio inca y del gobierno virreinal. El cronista subrayó la utilidad moral de su obra como herramienta favorable a la conversión cristiana de aborígenes y a la destrucción de idolatrías (p. 1). El autor aglutinó la idolatría en un mismo conjunto de maniobras demonolátricas que consideraba repulsivas; entre ellas: la hechicería, la brujería, el desenfreno sexual, la borrachera y la utilización ritual de la hoja de coca. Aunque este arbusto constituye un ancestral producto alimenticio con propiedades farmacológicas para los pueblos andinos ${ }^{2}$, existe en la Nueva corónica un rechazo de esta planta en calidad de instrumento satánico. Tal desdén guamanpomiano por la coca ha sido analizado por académicos como Ana Sánchez (1997) y Ramiro Castro (1977). Sánchez (1997), en su artículo "El talismán del diablo", sostiene que el tribunal de inquisición limeño repudió el arbusto de coca por considerarlo un artilugio diabólico de hechicería (p. 149). En "La coca en la obra de Guaman Poma de Ayala", Castro afirma categóricamente que la Nueva corónica siempre juzga la coca como un componente pernicioso para la salud física y religiosa de los indígenas (Castro, 1977, p. 63). Sin embargo, estos investigadores no señalan que el cronista andino no se decantó exclusivamente por reprobar o alabar el consumo de la coca ni 
examinan la indeterminación que fundamenta la postura de Guaman Poma de Ayala respecto a esta planta. En este artículo me concentro precisamente en la ambigüedad guamanpomiana respecto a la coca para argumentar que la Nueva corónica entraña un discurso flexible, el cual oscila entre dos polos aparentemente contradictorios pero, en última instancia, concordantes: el rechazo demonológico de las plantas psicoactivas ${ }^{3}$ y la consideración de la coca como un componente no necesariamente nocivo de la cultura inca. Además, argumento que la Nueva corónica movilizó estratégicamente la reprobación cristiana del consumo prohibitivo de fármacos psicotrópicos mediante el empleo de discursos propios de la demonología europea. Afirmo que la estrategia guamanpomiana consiste en repudiar el uso ceremonial de la coca mediante retóricas demonológicas sin necesariamente considerar este arbusto como un obstáculo insalvable para que los incas gobernaran el virreinato de Perú mano a mano con los españoles. Mediante un análisis textual e icónico, propongo demostrar que, aunque Guaman Poma de Ayala no se opuso de manera inflexible al empleo de la coca, se valió estratégicamente del rechazo cristiano hacia el uso religioso de plantas psicotrópicas. Esta estrategia le permitió al cronista andino defender la idea de que los incas tenían la capacidad de ejercer el poder político junto con los españoles sin entrar en conflicto directo con los presupuestos teológicos europeos. El entramado textual y pictórico de la Nueva corónica $y$ buen gobierno evidencia que sus dibujos no son simples ilustraciones que complementan un texto castellano aderezado con quechua, sino que constituyen parte integral de la obra. Por este motivo, a pesar de que Guaman Poma de Ayala se refiere a la coca en decenas de ocasiones, en este artículo me concentro en los pasajes en que tanto dibujo como descripción escrita coexisten para ofrecer visiones complementarias respecto a esta planta ${ }^{4}$.

El arte religioso, los manuales antisupersticiosos y los concilios eclesiásticos difundieron discursos demonólogicos que influyeron los procesos de extirpación de idolatrías presenciados por Guaman Poma en el virreinato de Perú. En el siglo V d. C., Agustín de Hipona sistematizó la demonología 
cristiana como el estudio del diablo y sus distintas manifestaciones terrenales ${ }^{5}$. No obstante, es recién en los siglos XVI y XVII cuando se da en Europa occidental una eclosión de discursos sobre el demonio. Por tal motivo, estas centurias se distinguen respecto a otras por su particular preocupación por el diablo. En su artículo "Las bocas del diablo", María Zamora (2008) arguye que, a partir de 1580, los manuales antisupersticiosos proliferaron aún más en toda Europa y difundieron ideas demonológicas (p. 419). En España, estos manuales propiciaron la divulgación de imágenes, tanto textuales como icónicas, que serían típicamente asociadas al diablo (e. g. la boca del infierno, el demonio como macho cabrío con garras puntiagudas, el típico aquelarre de brujas alteradas por plantas psicoactivas, entre otros). Por ejemplo, en su Reprovación de supersticiones e idolatrías, el teólogo Pedro Ciruelo (2003 [1538]) arguye que las brujas cometen sacrilegios embadurnándose el cuerpo con unturas psicotrópicas para asistir a aquelarres y realizar pactos nigrománticos con el diablo ${ }^{6}$ (p. 77). También los concilios eclesiásticos, impulsados por el desarrollo de la Contrarreforma, se dedicaron a perseguir herejías durante la segunda mitad del siglo XVI. Por ejemplo, el Concilio de Trento (15451563) reprobó la adoración de ídolos y supersticiones por considerar estos últimos como manifestaciones espurias de la fe cristiana ${ }^{7}$. El Concilio de Trento también institucionalizó doctrinas que se convertirían en instrumentos fundamentales de conversión en el llamado Nuevo Mundo, tales como las visitas pastorales. Estas inspecciones de asentamientos aborígenes buscaban introducir la doctrina católica ortodoxa y repeler herejías. En otras palabras, el visitador tenía por finalidad sustituir doctrinas no cristianas por otras prescritas por el Concilio ${ }^{8}$. El Concilio de Trento fue confirmado por Felipe II, quien ordenó que se siguieran sus dictámenes en el virreinato de Perú mediante una cédula real en 1564. Esta legislación reafirmaba que los arzobispos locales debían hacer cumplir las resoluciones del Concilio de Trento mediante la celebración de concilios provinciales, tales como el Tercer Concilio Limense ${ }^{9}$ (López, 2011, pp. 6-7). Las disposiciones de Trento no solo se manifestaron en las visitas pastorales en el virreinato de Perú, sino también en las campañas 
de extirpación de idolatrías. El propósito de estas últimas era arrancar de raíz cualquier elemento de las religiones andinas —incluido el empleo ritual de plantas psicotrópicas - por medio de herramientas doctrinales demonológicas y de la violencia física ${ }^{10}$. José Chaupis y Ricardo Aguilar (2016) argumentan que las visitas pastorales propuestas por los concilios eclesiásticos tuvieron un rol relevante en las campañas de extirpación de idolatrías en lugares remotos de la región andina (p. 172). Guaman Poma afirma haber trabajado, como intérprete, para Cristóbal de Albornoz, uno de los extirpadores de idolatrías que aplicó las disposiciones tridentinas en el virreinato peruano ${ }^{11}$. Este dato es fundamental para entender la visión del cronista andino, quien afirma que su trabajo al lado del visitador español constituyó su fuente primaria de conocimiento respecto a la religiosidad inca: “Todo lo escrito de los pontífeses lo sé porque fue serbiendo a Cristóbal de Albornós, uecitador general de la santa madre yglecia, que consumió todas las uacas ídolos y hecheserías del rreyno. Fue cristiano jues" (p. 282). Además de su contacto con Albornoz, el autor indígena también muestra consciencia de textos religiosos en que se codificaban basamentos de la doctrina cristiana aplicada en el Nuevo Mundo. En su "Las otras fuentes de Guamán Poma", Rolena Adorno (1978) argumenta que el cronista andino estaba familiarizado con la cultura letrada de su época. Por ejemplo, el intérprete de Albornoz conocía las argumentaciones favorables a las aborígenes difundidas por Bartolomé de Las Casas ${ }^{12}$ y fray Domingo de Santo Tomás (1978, p. 138), sabía de las obras escritas por participantes del tercer concilio limense como José de $A_{c o s t a}{ }^{13}$, Luis Gerónimo de Oré y Miguel Cabello Valboa (1978, p. 140) y probablemente se enteró de las ideas de la "restitución cristiana" mediante las obras del arzobispo Loaysa (1978, p. 143). También es crucial tomar en cuenta que la actitud antiidolátrica en el texto de Guaman Poma se enmarca en una época especialmente intensa de la persecución contra la religión inca. Uno de los eclesiásticos que persiguió con más ahínco los sistemas de creencias andinos fue Francisco de Ávila. Este sacerdote había sido nombrado inspector de idolatrías en la zona de Huarochirí (sierra de Lima) en 1610 y realizó esta labor hasta 1615. Precisamente en estos 
años el cronista andino estaba finalizando su manuscrito (Adorno, 1978, p. 154). Por ende, Guaman Poma tuvo múltiples oportunidades de entrar en contacto con la teología demonológica europea, la cual fue utilizada estratégicamente por el cronista andino para forjar su retrato de la coca.

Cuando el cronista andino representa la utilización de la coca como una práctica deleznable, suele valerse de tópicos demonológicos que pueden verificarse en diferentes fuentes textuales y pictóricas europeas (manuales antisupersticiosos, actas de concilios eclesiásticos, xilografías occidentales). Algunas de estas concepciones demonológicas son la noción del diablo como amo manipulador y engañador de sus súbditos, el concepto de los idólatras, supersticiosos y hechiceros al servicio del diablo y la idea del desorden social provocado por el demonio y sus sirvientes (e. g. hechiceros, brujos, idólatras, etc.). Por ejemplo, en la primera parte de su obra, el capítulo duodécimo sobre los "ídolos", suele representar negativamente la religiosidad incaica al acusarla de idolátrica. En este apartado, se halla el dibujo de la página 270 titulado "ÍDOLOS Y I VACAS DE LOS ANDI SVIOS / Saua Ciray / Pitu Ciray / otorongo [jaguar] / en la montaña del Anti Suyo /" (figura 1) y su correspondiente texto escrito en la página siguiente. Tanto la narrativa verbal como la imagen icónica describen la adoración del árbol de coca por parte de los indios del Antisuyo. En el dibujo, arrodillado frente a un jaguar y a los huacas de la montaña, hay un hombre que porta un arco y un carcaj con flechas ${ }^{14}$. Tiene una vasija humeante entre sus manos. Lleva pelo largo y lacio y facciones tranquilas. Viste un unqu (i. e. túnica de hombre). Detrás de él, se encuentra una mujer noble del Antisuyo con un penacho en la cabeza. Ella lleva un niño en brazos. Se mantiene de pie mientras el infante extiende las manos hacia adelante. En la parte superior izquierda del dibujo, hay montañas coronadas con huacas sonrientes en sus cimas. Al pie de la montaña y enfrente de las dos personas de la derecha, hay un jaguar (otorongo) con su pata derecha levantada para sugerir movimiento: 


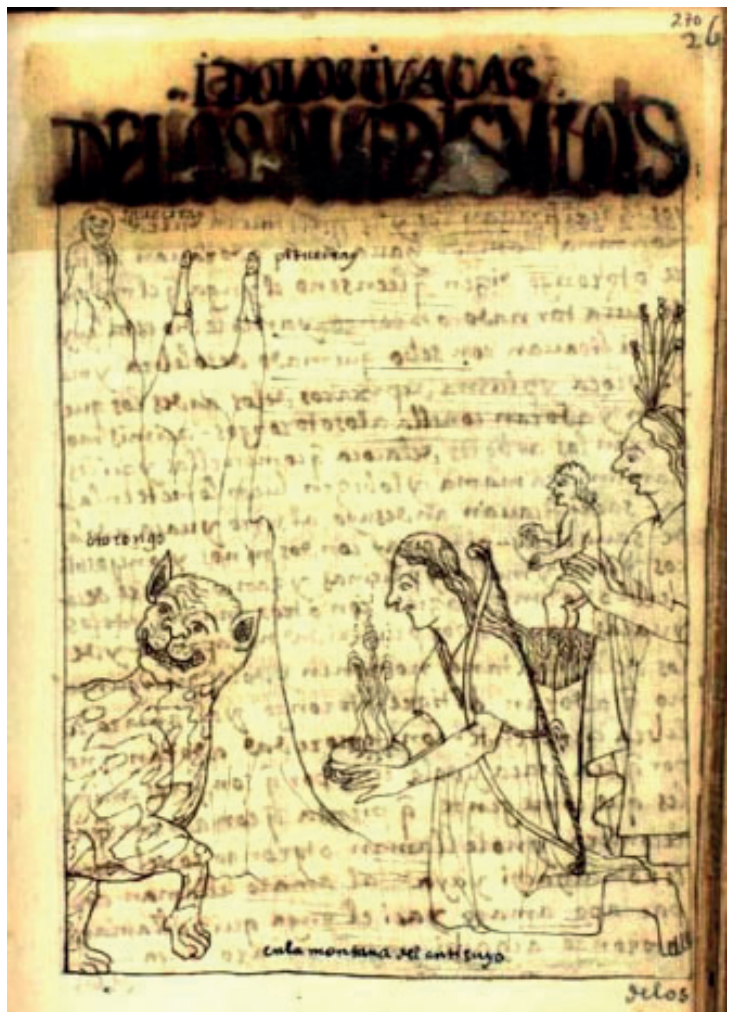

Figura 1. "ÍDOLOS Y I VACAS DE LOS ANDI SVIOS / Saua Ciray / Pitu Ciray / otorongo [jaguar] / en la montaña del Anti Suyo /". Nueva corónica y buen gobierno (1615), p. 270. Biblioteca Real de Copenhague, Dinamarca.

El texto escrito correspondiente en la página 271 demuestra que la vasija humeante contiene coca y que es adorada por los indios del Antisuyo. Guaman Poma describe el uso de la coca y de otros materiales empleados en ceremonias religiosas:

Sacrificauan los yndios questauan fuera de la montaña llamado Haua Anti; adorauan al ticre, otorongo. Dizen que le enseñó el Ynga que él mismo se auía tornado otorongo y ancí le dio esta ley y sacrificauan con sebo quemado de colebra y mays y coca y pluma de páxaros de los Andes; los queman y adoran con ella a los otorongos. (p. 271) 
El intérprete de Albornoz también subraya la adoración del arbusto de coca por parte de los Antisuyos: "Acimismo adoran los árbores de la coca que comen ellos y ací les llaman coca mama [la coca ceremonial] y lo bezen; luego lo mete en la boca” (p. 271). Guaman Poma traza correspondencias entre su dibujo y su narración escrita para enfatizar el propósito del capítulo duodécimo sobre los "ídolos". En otras palabras, el empleo de la coca como objeto de veneración y sacrificio entre los aborígenes del Antisuyo se asocia con el pecado cristiano de la idolatría. Por tal motivo, el cronista andino censura rituales en los que se ofrece coca y otros productos vegetales y animales a cualquier divinidad andina ${ }^{15}$. En el contexto de este capítulo sobre los “ídolos”, Guaman Poma de Ayala retrata a los indios del Antisuyo como idólatras, supersticiosos y hechiceros que no están al servicio del verdadero Dios cristiano, sino a disposición de huacas y animales como el jaguar. Este trastrocamiento de las jerarquías afirma la idea del desorden social provocado por el demonio y sus sirvientes (hechiceros, brujos, idólatras).

En este mismo capítulo sobre los ídolos, se halla el dibujo de la página 272 titulado "ÍDOLOS I VACAS DE LOS COLLA SVIOS / Uillca Nota / carnero negro / en el Collao // waqa /" (figura 2) y su correspondiente texto escrito en la página 273. Tanto la imagen icónica como la narrativa textual guamanpomianas se valen de elementos demonológicos para censurar el empleo ritual de la coca. En este dibujo, se ven dos hechiceros ofreciéndole dones a una divinidad ubicada en una montaña. Ambas personas llevan túnicas extensas, pelo largo y lacio sujeto por un sombrero ceñido por una media luna y collares con dijes redondeados. El hechicero de la izquierda sostiene por el cuello un carnero negro, típica ofrenda sacrificial al demonio en la teología cristiana: 


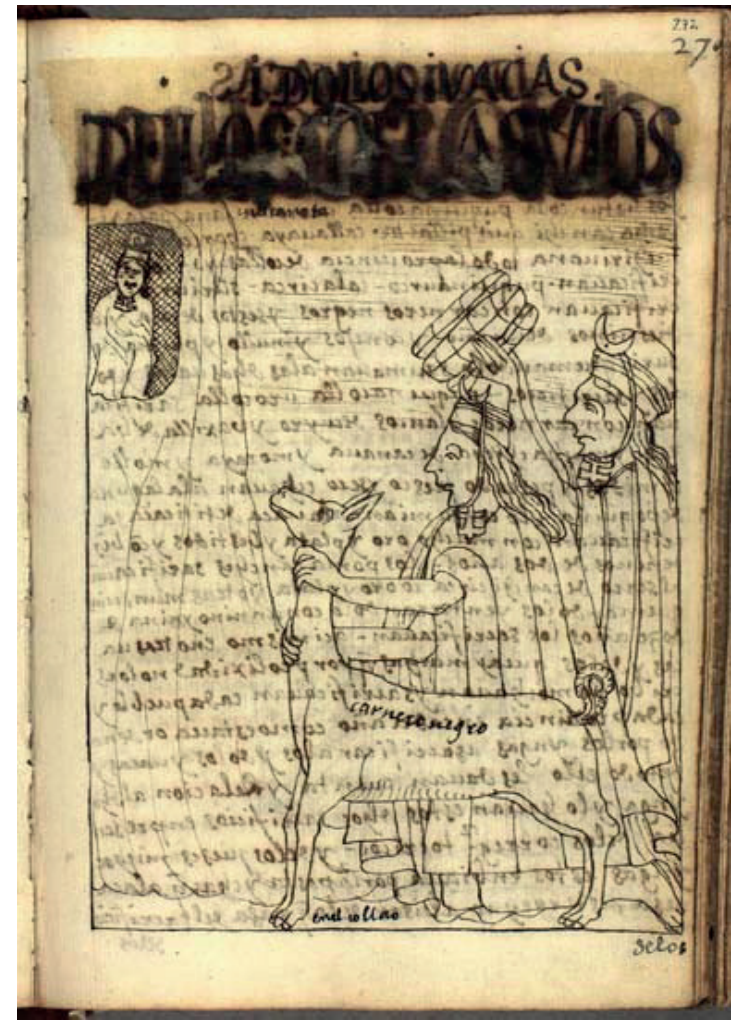

Figura 2. "ÍDOLOS I VACAS DE LOS COLLA SVIOS / Uillca Nota / carnero negro / en el Collao / / waqa /. Nueva corónica y buen gobierno (1615), p. 272. Biblioteca Real de Copenhague, Dinamarca.

La narración de esta escena explica que no solo animales, sino también seres humanos eran sacrificados a las deidades de las montañas: "sacrificauan con carneros negros y sestos de coca y con dies niños de un año y conejos y mullo [concha] y pluma de suri [avestruz]" (p. 271 [273]). Es decir, el cronista andino no se limita a mostrar eventos despreciados por la teología cristiana que, además, formaban parte de los discursos demonológicos (los sacrificios cruentos de animales y de niños de 1, 2 y 12 años), sino también el empleo de la coca para tales eventos ${ }^{16}$. Por ende, en este pasaje, el intérprete de Albornoz 
muestra la coca alineada con prácticas que el poder eclesiástico español de la época consideraba idolátricas y heréticas. Así, el cronista se asegura que el lector cristiano se identifique con su plataforma ideológica, la cual reproduce tópicos demonológicos bien recibidos en el quehacer editorial de la España tempranomoderna.

En contraste con los pasajes analizados hasta el momento, el dibujo de la página 279 (figura 3) y el texto escrito que sigue movilizan tópicos demonológicos de una manera más evidente y acre.

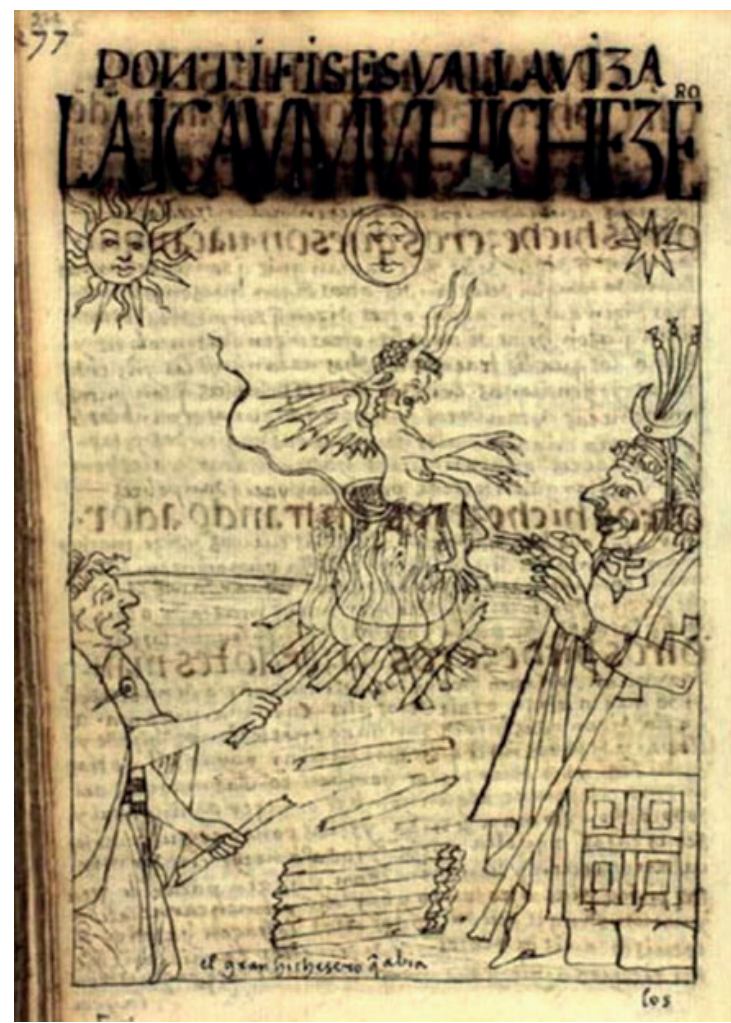

Figura 3. "Pontífises, vall viza, laica, vmv, hichecero / el gran hichesero que abía /". Nueva corónica y buen gobierno (1615), p. 279. Biblioteca Real de Copenhague, Dinamarca. 
En esta ilustración, Guaman Poma retrata dos astros de larga tradición astrológica con facciones humanas: el sol en la esquina superior izquierda y la luna en el centro, justo encima de un caldero ardiente ${ }^{17}$. Además, traza a la derecha del papel a Venus, el lucero del alba, encima de un siniestro hechicero. En la parte inferior izquierda, se encuentra una india anciana cuya lliclla (chal) se mantiene sujeta con un tupu (alfiler). Este chal, exclusivo de las mujeres andinas, deja entrever una banda con tokapu ${ }^{18}$. Ella está arrodillada poniéndole leña a una hoguera sobre la que hierve un caldero. El contenido de la olla no se puede determinar a partir del dibujo ${ }^{19}$; sin embargo, sentado sobre esta, flota un demonio desnudo con cola larga y curva, grandes cuernos ondulados, orejas y nariz puntiagudas, alas que terminan en púas y manos y pies rematados por uñas afiladas. Este diablo, retratado según la iconografía demonológica europea, extiende sus garras hacia el hechicero que se encuentra arrodillado en la parte inferior derecha de la imagen ${ }^{20}$. El hechicero, llamado camascona o "brujo", tiene afiladas uñas en sus manos extendidas hacia el caldero. La nariz del hechicero también es puntiaguda; su cara es sonriente, arrugada y con pelo rizado coronado por una banda con una media luna y un penacho ${ }^{21}$. Su actitud sonriente, su collar, sus brazaletes y su capa contrastan con la representación de la mujer que alimenta el fuego. El texto escrito correspondiente devela el contenido del caldero y el propósito adivinatorio del ritual:

Otros hichezeros toman zebo de carnero y de culebra y de león y de otros animales y may[s] y sangre y chicha y coca y lo queman y hazen hablar del fuego los demonios. Y lo pregunta y lo rresponde y dizen lo que a de auer y lo que pasa; por ellos lo sauen. Todos los que comen coca son hicheseros que hablan con los demonios, estando borracho o no lo estando y se tornan locos lo que comen coca. Dios nos guarde y ací no se le puede dar sacramento al que come coca. (p. 280)

De esta manera, el intérprete de Albornoz hace hincapié en que la ingestión de la coca y su empleo ritual por parte de los sacerdotes incas constituye pecado suficiente para que el infractor sea excluido de la comunidad cristiana mediante la prohibición de la comunión. Para Guaman Poma de Ayala, la idolatría de los hechiceros constituye una locura que va más allá de la ebriedad ${ }^{22}$. Para expresar esta opinión, el cronista andino presenta el concepto de los idólatras, 
supersticiosos y hechiceros al servicio del diablo. Este concepto se puede notar fácilmente en la ilustración de la página 279 , porque se retrata a dos personas al servicio del demonio. Por ende, aunque el hechicero de este dibujo tenga atributos de nobleza en su atuendo, sus comportamientos que invocan al demonio merecen — ante los ojos del cronista andino - ser censurados mediante la batería terminológica de la demonología europea.

Aunque el pasaje recién examinado evidencia la aplicación de discursos demonológicos al campo de la borrachera ritual andina, existe un caso en que la censura de la ebriedad es aún más directa. En el capítulo trigésimo titulado "de los indios de este reino" de la segunda parte de su crónica ("Buen gobierno"), se encuentra el dibujo "la borachera, Machasca [emborrachado]" (figura 4):

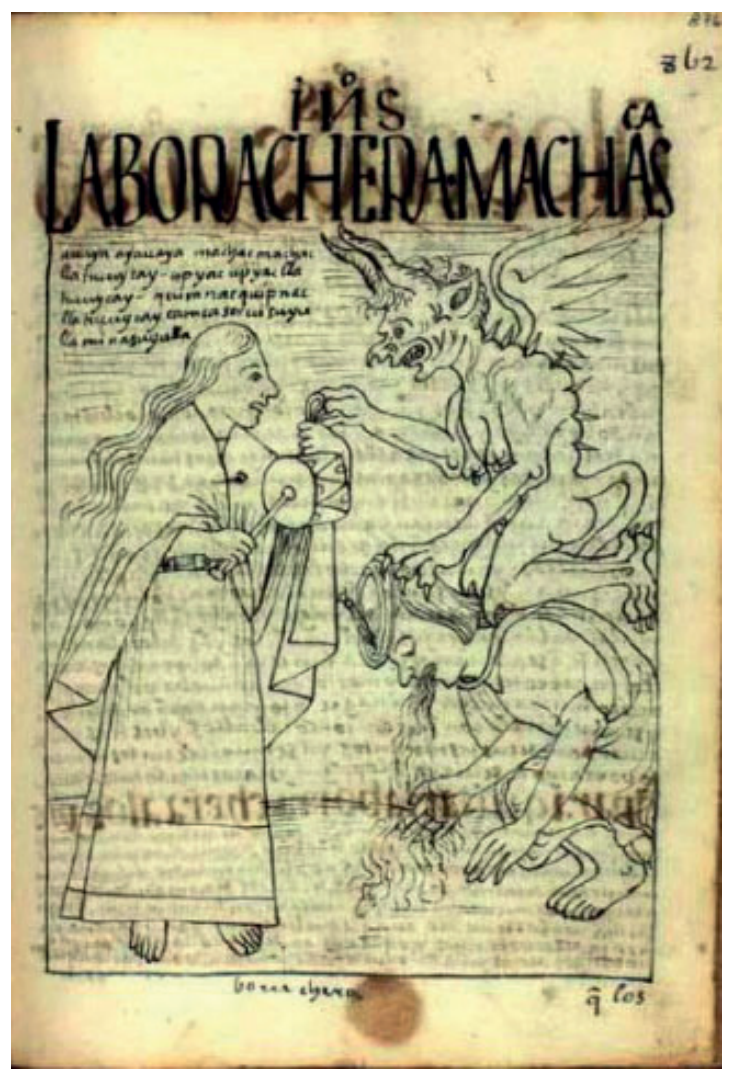

Figura 4. "la borachera, Machasca [emborrachado]". Nueva corónica y buen gobierno (1615), p. 876. Biblioteca Real de Copenhague, Dinamarca. 
Esta ilustración viene acompañada de un texto explicativo en quechua: "Auaya ayauaya! Machac, machaclla. Tucuy cay upyac, upyaclla. Tucuy cay quimnac, quipnaclla. Tucuy cay camca serui, suyulla. Mina suyulla. [¡Awaya, ayawaya! El borracho, es solo un borracho, el bebedor solo un bebedor, quien vomita, solo vomita. Lo que le toca es servirte, diablo. Las minas son lo que le toca.] / borrachera /"'. El cronista retrata tres figuras. En el lado izquierdo se encuentra una mujer de pelo largo que toca un tambor con la mano derecha. Lleva una lliclla ajustada con un tupu que cubre patrones de tokapu en la banda de su cintura. Esta mujer boquiabierta — como si estuviera cantando o rezando una invocación - parece contemplar a un demonio que flota encima de un hombre borracho que se inclina y vomita. Análogamente al dibujo de la página 279 (figura 3 ), el trazo de este demonio rememora la figura del diablo en la iconografía medieval y temprano-moderna: tiene cuernos ondulados y largos, nariz y orejas puntiagudas, alas de murciélago, garras afiladas en manos y pies, además de una cola alargada que está ahorcando al hombre ebrio. El demonio también tiene protuberancias puntiagudas en su espina dorsal. Con todo, este diablo presenta dos rasgos particulares: senos colgantes y glúteos protuberantes, los cuales podrían sugerir que se trata de un demonio femenino ${ }^{23}$. El hombre arrodillado que vomita lleva una camisa de mangas cortas y una cinta en la cabeza que sostiene una pluma. El demonio se retrata como promotor directo de la emesis del indio, puesto que empuja al arrodillado con su garra derecha. La narración verbal asociada a esta ilustración profundiza la movilización guamanpomiana de los tropos demonológicos respecto a la ebriedad. Tal como afirma Mónica Morales en su artículo "Inebriation Imagery”, las dicotomías occidentales de moderaciónexceso, autocontrol-caos, bien-mal y virtud-vicio presuponen que el exceso, el caos, el mal, el vicio y la irracionalidad constituyen rasgos propios de la ebriedad que ponen en peligro el orden social y la salvación en el mundo cristiano (2009, p. 449). Guaman Poma de Ayala se sirve de tales dicotomías y las sazona con tópicos demonológicos para presentar un retrato negativo de la beodez. El cronista andino sostiene que, aunque el virrey Francisco de Toledo buscó eliminar la borrachera, tal supresión no se ha logrado porque los indios no hacen caso: "Que para quitar 
la borrachera a los yndios y comer coca, no hallo otro rremedio, penas ni castigos. No hazen caso" (p. 877). El traductor de Albornoz argumenta que la borrachera promueve que los indios cometan iniquidades como el incesto, el adulterio y la idolatría: "Que los dichos yndios estando borracho el más cristiano, aunque sepa leer y escriuir, trayendo rrozario y bestido como español, cuello, parese santo, en la borrachera habla con los demonios y mocha [reverencia] a las guacas ýdolos" (p. 877). Por consiguiente, de este retrato tan peyorativo de la ebriedad se colige que el cronista andino consideraba que uno de los mayores obstáculos para la evangelización de los indios era el consumo de sustancias psicoactivas en la colonia, principalmente si se practicaba en un entorno ritual que evocaba al demonio. De esta manera, Guaman Poma de Ayala se alineó con la ortodoxia cristiana de la Contrarreforma, la cual consideraba la borrachera como una conducta aberrante que atentaba contra la integridad del alma, específicamente en contra de la voluntad del afectado. Por ende, el cronista andino subraya en su imagen icónica y en el texto escrito concomitante la noción del diablo como amo manipulador y engañador de sus súbditos.

En contraste con los ataques a los sistemas de creencia incaicos abordados en el párrafo anterior, existen pasajes en la Nueva corónica que retratan la utilización de la coca como un fenómeno no necesariamente pernicioso en la cultura inca. En el capítulo 18, titulado "El capitulo del gobierno del Ynga", el cronista andino retrata icónica y textualmente a un alguacil mayor inca ( $\mathrm{p}$. 346). Esta autoridad civil porta una chuspa (bolsa) de coca como símbolo de autoridad, no de ebriedad idolátrica. La ilustración contiene múltiples signos que subrayan la nobleza del personaje: un unqu largo y amarrado al nivel del pecho y con diseños geométricos propios del tokapu en la base, orejeras, una corona en la cabeza ceñida con flores y plumas. Además, presenta una insignia de mando, "ojotas" (sandalias) del inca y una chuspa que contiene coca (p. 344; Castro, 1977). A pesar del subtítulo de chacnai camaioc (torturador), en la ilustración no hay rasgos negativos demonológicos en la representación de este personaje: 


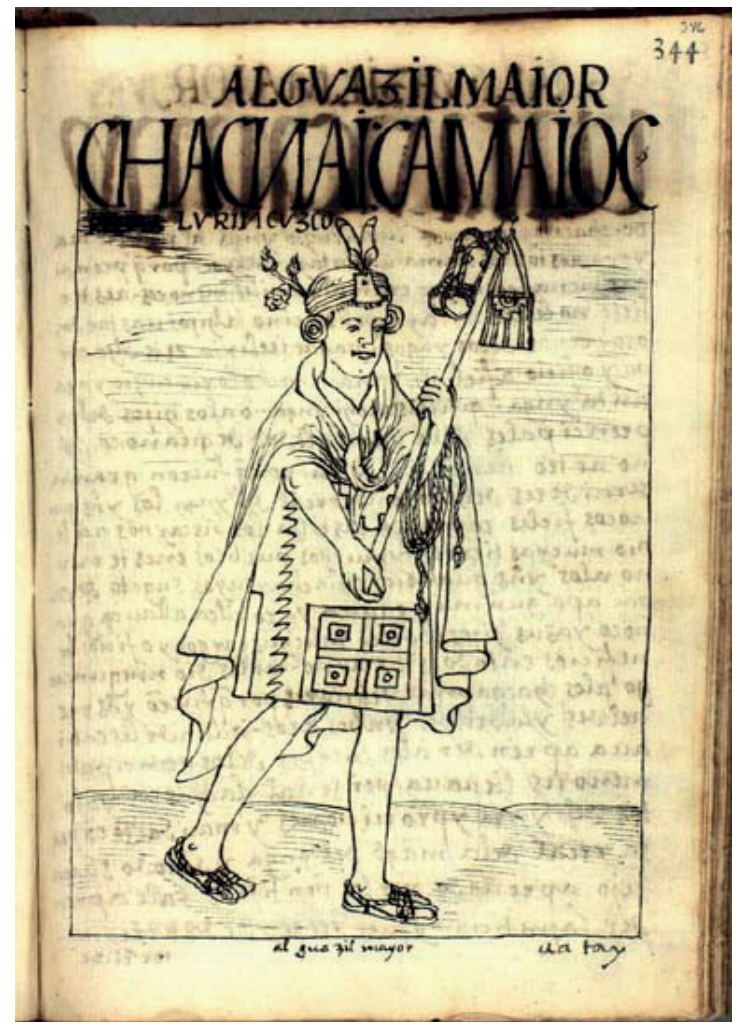

Figura 5. "ALGVAZIL MAIOR, CHACNAI CAMAIOC [torturador], LVRIN CVZCO”. Nueva corónica y buen gobierno (1615), p. 346. Biblioteca Real de Copenhague, Dinamarca.

El texto escrito es consecuente con la imagen icónica al presentar la coca como un símbolo de autoridad: "Quando les enbiaua a prender a los cuerpos de los indios ales menores, lleuaua por señal la chuspa [bolsa] y ojotas [sandalias] del Ynga" (p. 347). Esta representación neutra, y a veces positiva, de la organización política en tiempos de dominio inca se halla dispersa en toda la crónica, aunque no siempre viene potenciada por una representación pictórica. Sin embargo, al leer los múltiples pasajes en que la utilización de la coca no constituye una amenaza para el orden social, detecto un patrón que apunta a una reivindicación del orden social farmacológico impuesto por el inca. 
En múltiples lugares de su obra, Guaman Poma de Ayala incluye el cultivo de la coca entre los elementos necesarios para que el virreinato del Perú funcione apropiadamente. "El capítulo de los indios de este reino" se encuentra en la segunda parte de la crónica, llamada "Buen gobierno". En el dibujo de la página 879 , titulado "Ortelano, Pachacacvna", se observan dos ancianos, uno sentado a la izquierda y otra hincada a la derecha. Ambos hortelanos se ven tranquilos, sin una sonrisa macabra como la del hechicero del dibujo de la página 279:

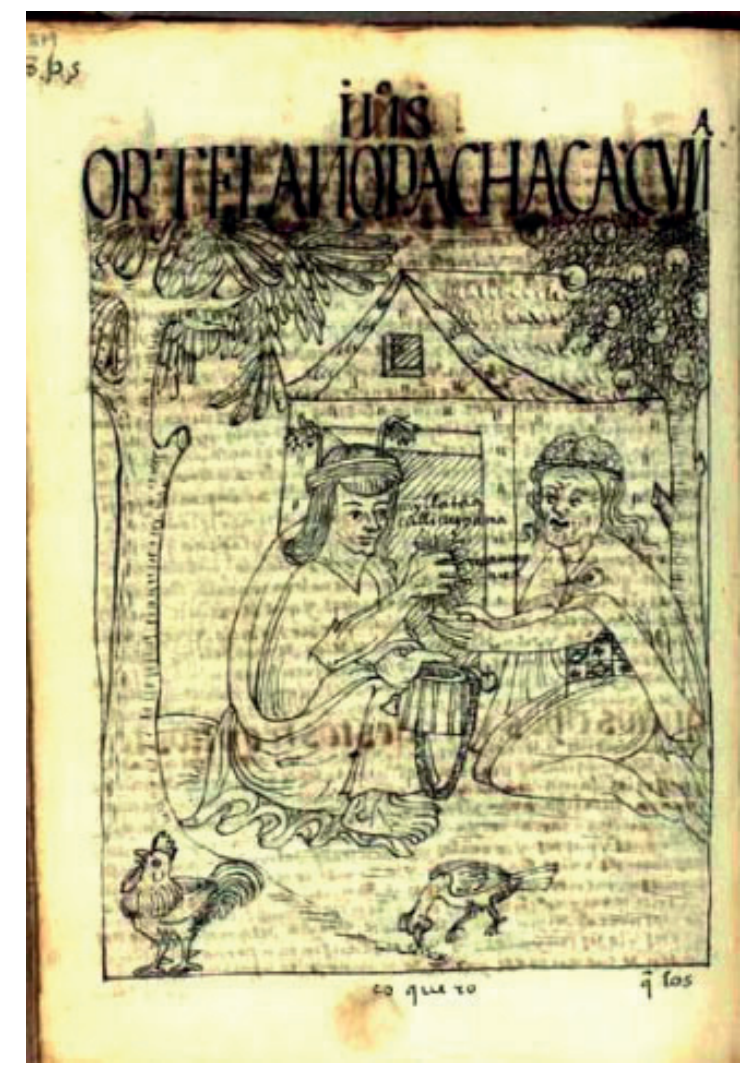

Figura 6. "Ortelano, Pachacacvna [hortelanos]". Nueva corónica y buen gobierno (1615), p. 879. Biblioteca Real de Copenhague, Dinamarca.

Ambos personajes están frente a una casa con un techo a dos aguas cerca de dos árboles. El árbol de la izquierda tiene hojas alargadas y grandes vainas 
porque, tal como el propio dibujo lo explica, es un árbol de guaba (Inga feuillei); el de la derecha tiene hojas pequeñas con frutos redondeados. El anciano viste una camisa y una larga capa que redobla en su regazo. Alrededor de su cabeza, lleva una banda que sostiene dos flores enhiestas. Con la mano izquierda sostiene una chuspa (i. e. una bolsa) de la que saca un puñado de hojas de coca para la anciana. Esta viste una lliclla sostenida por un tupu, una falda larga y una banda con tokapu. El anciano le dice en quechua: "Cayllata acullicuy, pana" [Hermana, masca esta coca]. La hortelana le responde: "Apomoy, tura" [Tráela, hermano] y extiende sus manos para recibirla. El texto escrito correspondiente en las páginas 880-881 procura más detalles sobre la labor de los hortelanos y la importancia de los árboles de guaba y de durazno en las huertas. También censura las cohabitaciones sexuales de las indias con los españoles entre otros muchos detalles. No obstante, no se menciona la hoja de coca, aunque esta ostenta un papel central en la ilustración. En el texto escrito y en su correspondiente dibujo, el cronista andino plasma un consumo de la coca que no incorpora elementos peyorativos o demonológicos presentes en otros pasajes: no hay hechiceros realizando invocaciones satánicas, las ideas del desenfreno sexual están ausentes, la adoración de los huacas brilla por su ausencia. Por el contrario, Guaman Poma subraya en los textos icónico y verbal que la agricultura es necesaria para el bienestar del virreinato, por lo que la coca no constituye un obstáculo para que se gobierne eficientemente el reino. Por tal motivo, en otros lugares, el traductor de Albornoz recomienda que, en la administración del Estado, se incluya la siembra de frutas y de coca ${ }^{24}$. Igualmente, sugiere tasar la coca y otros productos para que así aumente la recaudación fiscal del virreinato ${ }^{25}$. Por consiguiente, Guaman Poma aboga por la regulación del empleo de la coca y no la extinción de su uso. Con esta apuesta regulatoria, el cronista andino sugiere que, en relación con el uso de la coca, la regulación del imperio incaico es superior al manejo administrativo virreinal.

Al efectuar acérrimas críticas al empleo de la coca en ceremonias religiosas y en circunstancias que conllevan borrachera, el cronista andino también critica veladamente políticas de la administración virreinal española. Si 
bien el intérprete de Albornoz no desafía solapadamente la autoridad española en el virreinato del Perú, introduce subrepticiamente la idea de que la coca no es siempre perniciosa. En otras palabras, Guaman Poma de Ayala sostiene que la utilización de la coca no implica necesariamente la noción del diablo como amo manipulador y engañador de sus súbditos, el concepto de los idólatras supersticiosos y hechiceros al servicio del diablo, o la idea del desorden social provocado por el demonio y sus sirvientes. En primer lugar, el cronista andino arguye que el orden precolonial del imperio inca implicaba tanta severidad en relación con el consumo de la coca que cualquiera que se emborrachara de manera no autorizada era castigado severamente ${ }^{26}$. Segundo, Guaman Poma argumenta que la administración virreinal española ha traído desorden en la relación de los incas con la coca, porque este arbusto se ha convertido en uno de los productos a través de los cuales los conquistadores españoles explotan a los indios ${ }^{27}$. En último lugar, el traductor de Albornoz afirma que, si no hubiera borrachera en las fiestas andinas, estas serían prácticamente iguales a las de los cristianos ${ }^{28}$. De estas nociones críticas al gobierno español y parcialmente elogiosas al ejercicio de poder incaico, se colige un proceso de igualación entre incas y españoles. Tal nivelación concuerda con la idea guamanpomiana de que la administración del virreinato del Perú debe ser compartida por ambas naciones. A la luz de esta premisa cobra sentido que Guaman Poma insista en que, después del diluvio bíblico, uno de los hijos de Noé llegó a los Andes y dio lugar a la raza andina. Según esta perspectiva, tanto andinos como europeos descienden de patriarcas bíblicos, por lo que ambos son descendientes del Dios verdadero (pp. 25, 49, 74-75, 911, 53, 54, 56). El traductor de Albornoz refuerza esta conexión del pueblo andino con figuras icónicas del cristianismo cuando arguye que San Bartolomé visitó los Andes para evangelizar a los nativos (pp. 92-93). El cronista indígena colige de tales ópticas igualitaristas que la institución de la encomienda, entendida como el intercambio de trabajo y recursos naturales nativoamericanos por evangelización cristiana, era inútil e injusta, porque los incas ya estaban en contacto con el Dios cristiano (pp. 549, 550, 559, 915, 958). Tanto la encomienda como el corregimiento constituían instituciones coloniales mediante las cuales 
los conquistadores españoles controlaron la mano de obra aborigen y los vastos territorios americanos. El cronista andino criticó la crueldad de tales prácticas como parte de su proceso de nivelación. Este proceso igualitarista implicó el señalamiento de fortalezas y debilidades en los sistemas culturales español e inca, para así allanar el camino hacia un posible gobierno virreinal conjunto entre europeos y nativos andinos.

Por ende, tal como compruebo con este estudio, la representación guamanpomiana del uso y consumo de la coca no es monolítica sino ambigua. Aunque el cronista suele utilizar elementos de la demonología europea para retratar el empleo de esta planta, en algunos pasajes de su obra deja claro que un consumo regulado de la misma no impide que el virreinato se desarrolle ordenadamente. Argumento que precisamente en este punto yace el uso estratégico de la demonología que hace Guaman Poma: mientras censura los empleos rituales de la coca en el marco de la religiosidad inca, subraya la necesidad de proteger la integridad física y el poder de gestión política de los mismos. Esta capacidad de gobernar se comprende cuando se estudia esta noción política a la luz de los argumentos igualitaristas ya planteados. Al utilizar elementos de la retórica demonológica, el cronista está atrayendo hacia sí la simpatía de sus posibles lectores cristianos. No obstante, simultáneamente pone en marcha procedimientos que retratan positivamente a la sociedad inca y el uso regulado de la coca en contextos económicos y civiles. Por ejemplo, el cronista hace continuas referencias verbales a elementos de la cultura inca mediante el uso del quechua. Dado que nunca traduce nada del quechua al castellano, Guaman Poma simplemente incorpora terminología inca que el lector castellano no puede ver de soslayo. Gracias a este modo de escritura, un lector europeo se habría puesto en contacto con la cultura andina voluntaria o involuntariamente. Tal contacto incrementa las posibilidades de desarrollar una empatía con los andinos.

Hubo varios motivos para que Guaman Poma escribiera de una manera ambigua acerca de la coca: la promoción de un gobierno compartido entre indios y españoles, la devolución de las tierras a los indios explotados por los 
conquistadores y la abolición de encomiendas y corregimientos, en tanto eran instituciones destructivas e injustas. Estas tres ideas permean el texto de Guaman Poma porque son premisas axiales que recorren todo el entramado de la crónica. Por ende, el recurso a la retórica demonológica del cronista funciona como una estrategia política y discursiva que conlleva una abierta censura en contra de un elemento de la sociedad andina (i. e. la borrachera y la utilización ritual de la coca en ceremonias "idolátricas"). Tal reprobación tiene un posible fin específico: la introducción velada de una serie de reivindicaciones sociales a favor del gobierno inca. Así, la representación del empleo de la coca efectuada por Guaman Poma de Ayala en Nueva corónica y buen gobierno muestra una flexibilidad ideológica que se manifiesta ya en el título de su carta al rey, porque este alude a los tiempos de dominio incaico y a la época virreinal. La interacción entre las cosmovisiones nativa y cristiana hace convivir en una misma obra el repudio cristiano hacia el empleo religioso de plantas psicotrópicas y una perspectiva neutra $-\mathrm{y}$ a veces positiva - respecto a las funciones económica y social del arbusto de coca.

Tal como afirma Adorno, el cronista andino requirió de un "sistema simbólico" que hiciera su texto "simultáneamente inteligible y aceptable" tanto para españoles como para indios letrados (1978, p. 141). Las técnicas pictórica y escrituraria del intérprete de Albornoz evidencian que la Nueva corónica y buen gobierno manifiesta simultáneamente la apropiación de imágenes demonológicas y la movilización de indicadores de jerarquía social inca como los tupus, los tokapus, orejeras, tocados, entre otros. Esta simultaneidad de códigos culturales cristianos e indígenas respecto del consumo de la hoja de coca refleja una ambigüedad que le permitió al cronista andino defender sus ideas sobre la soberanía inca.

\section{Notas}

1 Todas las citas textuales provienen de la edición digital, con paginación corregida, que se puede consultar aquí: http://www.kb.dk/permalink/2006/poma/info/en/frontpage. htm (Guaman Poma, 2001 [1615]). En adelante, solo se indicará el número de página en las referencias a esta obra.

2 Kkoka es un vocablo de la lengua aimara que significa "árbol" (Rästch, 2005, p. 242; 
Villagrán y Castro, 2004, p. 232) o "arbusto" (Sánchez, 1997, p. 141). El uso de esta planta por parte de pueblos sudamericanos es ancestral y precede a la consolidación del imperio incaico (Naranjo, 1981, p. 163). La evidencia arqueológica más antigua del consumo de la coca data de alrededor de 3000 a. C (Rästch, 2005, p. 242). Además de tener valor nutricional, la hoja de coca se mastica o se consume en infusión para estimular los centros de placer, aliviar temporalmente el cansancio, remediar el mal de altura y estimular el sistema nervioso (Sánchez, 1997, pp. 141-142). Para un perfil científico de su utilización alimenticia y farmacológica, véase Henman y Metal (2009). Ni Sebastián de Covarrubias (1611) ni Diego González Holguín (1989 [1608]) registran las voces "coca", "koka", "kuka" o "khoka" en sus diccionarios. Fray Domingo de Santo Tomás, autor de la primera gramática quechua conocida, afirma que el arbusto de coca era de suma relevancia para los incas en el campo ritual, pragmático y recreativo (2006 [1560], p. 251).

3 Defino plantas psicoactivas o psicotrópicas como aquellos productos vegetales que alteran cómo piensa, se comporta o se siente una persona respecto a su estado de ánimo (Venes, 2013, p. 1941).

4 Para una compilación de lugares en los que Guaman Poma menciona la coca, véase Castro (1977). A pesar de que me concentro en los sitios en que se da un contrapunteo entre imagen icónica y texto verbal, los múltiples pasajes que contienen una alusión exclusivamente verbal al consumo de la coca confirman los argumentos que planteo en este artículo.

5 Para una lista de las obras en que Agustín desarrolla su demonología, véase Kors y colaboradores (2001, pp. 43-44).

6 Estas imágenes también circulaban en esferas literarias europeas. Por ejemplo, véase el ritual que la bruja Cañizares realiza con un ungüento psicotrópico en el Coloquio de los perros de Miguel de Cervantes.

7 Las actas del Concilio de Trento (1847, p. 229) definen la superstición como "verae pietatis falsa imitatrix" ("Falsa imitadora de la verdadera piedad"; la traducción es mía).

8 La sesión XXIV, capítulo III, de las actas del Concilio de Trento define las visitas pastorales como instrumentos para la promoción de la fe cristiana y la destrucción de herejías: "Visitationum autem omnium istarum praecipuus sit scopus, sanam, orthodoxamque doctrinam, expulsis haeresibus, inducere: bonos mores tueri, pravos corrigere: populum cohortationibus, et admonitionibus ad religionem, pacem, innocentiam accendere" ["El objetivo principal de estas visitas debe ser la promoción de sana y ortodoxa doctrina mediante la expulsión de herejías; fomentar las buenas costumbres y corregir las malas; incitar al pueblo mediante exhortaciones y admoniciones dirigidas a la religión, la paz y la inocencia"] (1847, p. 295; la traducción es mía).

9 Al Tercer Concilio Limense se le ha llamado el "Trento latinoamericano" (Morong, 2014, p. 44). 
10 José Chaupis y Ricardo Aguilar definen la institución de la extirpación de idolatrías como un esfuerzo de los curas doctrineros para evangelizar a los aborígenes mediante la erradicación de las supuestas prácticas paganas de los indios (2016, p. 170). Afirman que hubo tres campañas principales, de las cuales la primera, dirigida por Francisco de Ávila, fue la más relevante (2016, p. 171). Esta primera arremetida de la extirpación de idolatrías coincidió con los años de escritura de la Nueva corónica y buen gobierno (Chaupis y Aguilar, 2016, p. 171).

11 En la página 690, Guaman Poma de Ayala expresa su admiración por Albornoz. Afirma que el visitador español fue un bravo juez que castigó tanto a indios como a sacerdotes que perpetraban crímenes contra la Iglesia.

12 Adorno comprueba que los principios de El tratado de las doce dudas lascasiano están presentes puntualmente en el capítulo de la crónica guamanpomiana denominado “conzederaciones" (Guaman Poma, 2001 [1615], p. 915; Adorno, 1978, pp. 145-146).

13 Adorno arguye que el cronista andino leyó el Tercero catecismo y exposición de la doctrina chrisitina por sermones (1978, pp. 148-149). Esta obra sintetiza las resoluciones alcanzadas en el Tercer Concilio Limense.

14 El arco y las flechas son atributos de los indios del Antisuyo.

15 Véase también el siguiente pasaje sobre la ofrenda de coca y maíz que un creyente le dedica a una cueva objeto de adoración: "“Cueua, no me comáys. Hasme dormir bien y guárdame esta noche"” Deziendo esto, le dan de comer maýs mascado o coca y le enplasta al dicho cueua y hasta este tienpo lo uzan los yndios" (p. 278).

16 Para la teología cristiana de la temprana modernidad, el sacrificio cruento de Cristo en la cruz removió la necesidad de ofrecerle a Dios víctimas sangrientas de animales o humanos. En tal sentido, el cristianismo de la época consideraba que tales derramamientos de sangre eran propios de pueblos que no conocían la ley de Cristo, por lo que eran considerados bárbaros. Esta retórica, la cual también se aplicó a las religiones mesoamericanas que practicaban sacrificios cruentos, constituyó una herramienta de rechazo y de control cristianos de las naciones aborígenes americanas.

17 Véase el texto de Andreae Alciati para observar emblemas que retratan astros celestiales personificados (1534, pp. 60, 57, 68). Véase también la “crónica de Núremberg”, la cual incluye un grabado en el que el sol y la luna presentan caras humanas y resplandores similares a los dibujados por Guaman Poma (Schedel, 1493, p. LXXVIr).

18 El tokapu es el cuadrado multicolor con diseños geométricos que determinaba jerarquías en el imperio incaico.

19 El caldero también forma parte de la iconografía demonológica que retrataba a las brujas mezclando sustancias para preparar ungüentos psicotrópicos. Por ejemplo, véase en Molitoris (1489) la xilografía de dos brujas preparando una poción en un caldero.

20 La influencia demonológica europea se puede entender mediante la observación de los demonios del Juicio final de Hans Memling (c. 1460) o en la xilografía impresa en la portada del panfleto anónimo A rehearsall both straung and true (1579). 
21 Este penacho, los diseños de tokapu en su túnica y el colgante del cuello lo identifican como miembro de la etnia colla, la cual tenía como territorio la zona de la actual Bolivia.

22 En Occidente, los conceptos de "borrachez", "ebriedad", "beodez", "embriaguez”, etc., normalmente se aplican de manera exclusiva a los efectos del alcohol sobre el cuerpo humano. No obstante, en este ensayo entiendo la ebriedad en un sentido general que describe los efectos de cualquier planta psicotrópica en el cuerpo humano. Sin embargo, durante la Temprana modernidad española, estos vocablos también se aplicaban a borracheras no etílicas, como en el caso de algunos herbarios de la segunda mitad del siglo XVI (véanse Laguna, 1555, p. 369; Monardes, 1574, p. 115r y Acosta, 1578, p. 361). En cualquier caso, Guaman Poma de Ayala suele referirse a la borrachera como el efecto concurrente de varias sustancias en el cuerpo humano como la chicha, la coca, el vino y, a veces, el tabaco (cfr. pp. 336, 777, 780, 811, 872, 941, etc.).

23 Para la posible identificación de este demonio femenino con hapuñuñu (divinidad femenina andina), véase Quispe-Agnoli (2014, p. 58).

24 Sobre el modo en que los incas han de crear riqueza, Guaman Poma hace hincapié en la relevancia de la agricultura: "an de tener hazienda de comunidad que ellos les llama sapci, de sementeras de maýs y trigo, papas, agí, magno [verdura seca], algodón, uiña, obrage, teñiría, coca, frutales" (p. 977).

25 Respecto al pago de aranceles por la coca, el intérprete de Albornoz arguye lo siguiente: "Un uarco de coca en los Andes, dos rreales; en la cierra, quatro rreales" (p. 707).

26 Guaman Poma explica este fenómeno así: “Cómo ay en esta uiuida [sic] más borrachos los yndios que de los antigos. En tienpo del Ynga no lo auía nenguno ni jamás lo ubo por la buena justicia que abía" (p. 872). Agrega el cronista inca que debe seguirse aplicando la rigurosidad del imperio inca en el virreinato de Perú: "Y es justo que sea castigado luego que lo uea al borracho y al coquero cin enformación alguna, hallándole borracho al yndio, a la yndia" (p. 872). El traductor de Albornoz también afirma que el gobierno español ha contribuido a la propagación de la ebriedad entre los indios: "En lo demás, mayormente les mata a los yndios la borrachera, el mosto y uino, la chicha y la coca, el azogue. Teniendo en la boca todo el día, traga el polbo con la coca. Y ací en el corasó[n] se detiene este polbo y la coca y ancí muere azogado. Como tengo dicho, que en tienpo de los Yngas no había borrachera. A cido gran daño de los yndios la uenida de don Francisco a este rreyno. Conzedera” (p. 965).

27 Respecto a los curas doctrineros, el cronista inca afirma lo siguiente: "Cómo los dichos padres y curas de las dotrinas destos rreynos piden yndios y carneros para tragenear uino, agí, coca, maýs. Algunos tragenean en las espaldas de los yndios y sacan de los llanos uino de la montaña, coca, y se mueren por entrar a tierra callente, ciendo serrano, con calenturas y frío. Y ci lo quiebra, le manda pagar al yndio" (p. 577).

28 "Ci los dichos yndios hiciesen cin borrachear las fiestas ni comer coca y cin ydulatrear, fuera fiesta de cristiano" (p. 877). 


\section{Referencias bibliográficas}

A rehearsall both straung and true (1579). A rehearsall both straung and true, of hainous and horrible actes committed by Elizabeth Stile, alias Rockingham, Mother Dutten, Mother Deuell, Mother Margaret, fower (i.e. four) notorious witches. British Library. Recuperado de https://www.bl.uk/collection-items/witchcraft-pamphlet-a-rehearsalboth-strange-and-true-1579

Acosta, C. (1578). Tractado de las drogas y medicinas de las Indias Orientales, con sus plantas debuxadas al biuo por Christoual Acosta. Martin de Victoria.

Adorno, R. (1978). Las otras fuentes de Guaman Poma: Sus lecturas castellanas. Histórica, 2(2), 137-158. Recuperado de: http://revistas.pucp.edu.pe/ index.php/historica/article/view/7828

Alciati, A. (1534). Emblematvm libellvs. Basilea: Christianus Wechelus.

Castro, R. (1977). La coca en la obra de Guaman Poma de Ayala. Boletín del Instituto Riva Agüero, 11, 57-79. Recuperado de: http://repositorio.pucp. edu.pe/index/handle/123456789/114484

Chaupis Torres, J. \& Aguilar Saavedra, R. (2016). Guamán Poma de Ayala y la extirpación de idolatrías. En M. Mamani Macedo (Ed.), Guamán Poma de Ayala: Las travesías culturales (pp. 169-180). Lima: Ediciones Pakarina.

Ciruelo, P. S. (2003 [1538]). Reprovación de las supersticiones y hechizerías. Edición de J. Herrero. Salamanca: Diputación de Salamanca.

Concilio de Trento. (1847). El sacrosanto y ecumenico concilio de Trento. Traducción I. López. Barcelona: Imprenta de Ramón Martín.

Covarrubias, S. de. (1611). Tesoro de la lengva castellana, o española. Madrid: Luis Sánchez.

González Holguín, D. (1989 [1608]). Vocabulario de la lengua general de todo el Perú llamada lengua qquichua o del Inca. Lima: Fondo Editorial de la Universidad Nacional Mayor de San Marcos. 
Guaman Poma de Ayala, F. (1980 [1615]). Nueva corónica y buen gobierno. Edición de R. Adorno, J. Murra y G. Urioste. Madrid: Siglo XXI.

Guaman Poma de Ayala, F. (2001 [1615]). El sitio de Guaman Poma. Nueva corónica y buen gobierno. Copenhague: Biblioteca Real. Recuperado de http://www.kb.dk/permalink/2006/poma/info/en/frontpage.htm

Henman, A. \& Metaal, P. (2009). Los mitos de la coca. Ámsterdam: Transnational Institute.

Kors, A., Kors, A. C., \& Peters, E. (Eds.). (2001). Witchcraft in Europe, 400-1700: A Documentary History. Filadelfia: University of Pennsylvania Press.

Laguna, A. y Dioscórides. (1555). Dioscorides anazarbeo. Acerca de la materia medicinal y de los venenos mortiferos. Anuers: Casa de Iuan Latio.

López Lamerain, M. C. (2011). El concilio de Trento y Sudamérica: aplicaciones y adaptaciones en el III concilio limense. Anuario de Historia de la Iglesia en Chile, 29, 15-32.

Memling, H. (c. 1460). El juicio final [pintura]. Gándsk: Museo Nacional de Gdánsk.

Molitoris, U. (1489). De lamiis et phitonicis mulieribus. Reutlingen: Johann Otmar.

Monardes, N. (1574). Primera, segunda y tercera partes de la historia medicinal de las cosas que se traen de las Indias Occidentales que sirven en medicina. Casa de Alonso Escriuano.

Morales, M. (2009). Inebriation Imagery and Epistemic Shift: The Case of Guaman Poma de Ayala. Revista de Estudios Hispánicos, 43(3), 449-470.

Morong Reyes, G. (2014). El hechicero en el Perú: una aproximación histórica al discurso del Tercer Concilio Limense 1582-1583. Tradición y saber, 11(1), 21-52. Recuperado de: http://centroestudioshistoricos.ubo.cl/wpcontent/uploads/2015/10/2.-Morong-El-hechicero....pdf

Naranjo, P. (1981). Social Function of Coca in Pre-Columbian America. Journal of Ethnopharmacology, 3(2-3), 161-172. doi: 10.1016/0378-8741(81)90052-0 
Quispe-Agnoli, R. (2014). El silencio de Guamán Poma de Ayala ante Supay: de duende, espíritu y fantasma a diablo. Letras (Lima), 85(121), 47-61. Recuperado de http://revista.letras.unmsm.edu.pe/index.php/le/article/ view/251

Ratsch, C. (2005). The Encyclopedia of Psychoactive Plants. Rochester: Park Street Press.

Sánchez, A. (1997). El talismán del diablo. La Inquisición frente al consumo de coca (Lima, siglo XVII). Revista de la Inquisición, 6, 139-162. Recuperado de https://revistas.ucm.es/index.php/RVIN/article/view/ RVIN9797110139A

Santo Tomás, D. de. (2006 [1560]). Léxico quechua. Edición de J. Szemiñski. Lima: Ediciones El Santo Oficio.

Schedel, H. et alia. (1493). Registrum huius operis Libri cronicarum cu[m] figuris et ÿmagi[ni]bus ab initio mu[n]di. Núremberg: Anton Koberger.

Venes, D. (2013). Taber's Cyclopedic Medical Dictionary. Filadelfia: F.A. Davis Company.

Villagrán, C. y Castro, V. (2004). Ciencia indígena de los Andes del Norte de Chile: Programa interdisciplinario de estudios en biodiversidad (PIEB). Santiago de Chile: Fondo Editorial de la Universidad de Chile.

Zamora Calvo, M. J. (2008). Las bocas del diablo: Tratados demonológicos en los siglos XVI y XVII. Edad de Oro, 27, 411-445. doi: 10.15366/ edadoro2008.27 